Vol. 14, no. 6

Additional bibliography: Moldenke, Phytolog1a 7: 280-290. 1960; Angely, F1. Paran. 16: 38 (1960) and 17: 15. 1961; Reitz, Sellowia 13: 29, 4h--46, \& 109. 1961; Angely, Bibl. Veg. Paran. 195. 1964; Yoldenke, Résumé Suppl. 12: 3. 1965; Gooding, Loveless, \& Proctor, F1. Barbados 365-366 \& 465 . 1965.

Additional 1llustrations: Reitz, Sellowia 13: 45 \& 46. 1961.

Reitz (1961) calls the association in which this species grows the navicenieton. The Hahn 654, cited below, is a mixture with A. germinans (L.) L.

Additional citations: WINDWARD ISLANDS: Martinique: Hahn 654, in part (Ca-332488). TRINIDAD: Cowan \& Forster 1252 (ब) . BRAZIL: Ceara: Irouet 2548 (W-1594887). Guanabars: A. Castellanos 23460 [Herb. Cent. Pesq. Florest. 1720] (Ac); Scheiman 108 (JaII/108); J. Vidal s.n. [30/5/1934] (Ja-36839), s.n. [2I do Junho de 1934] (Ja-36838, Ja). Rio de Janeiro: Abreu s.n. [VIII/1925] (Ja-31572); Dusén 1963 (Ja-44852); Glaziou $1362(\mathrm{Ja}-21285)$; Schwacke 3MI [Herb. Saldanha 5962] (Ja- $44866, \mathrm{Ja}, \mathrm{Ja})$, s.n. [Mand, 16/I/1887] (Ja-44865); Ule 3884 (Ja--37434). Santa Catarina: Reitz 5088 (N); Reitz \& Klein 683 (W-2281838), 1183 $(\mathrm{Ca}-46892)$. Falhas Island: Nagainfles Correa s.n. [Oct. 1936] (Ja-30128). Gobernador Island: Rente \& Rente s.n. [18.II.1958] (Ac, Ja, Ja, Ja). Paqueta Island: Descartes $7 \overline{(\mathrm{Ja}-36350) .}$ Saravata Island: J. Vidal s.n. [Junho 1934] $(\overline{J a}-31546, \mathrm{Ja}, \mathrm{Ja})$.

AVICENNIA TOIDUZII Moldenke

Additional bibliography: Moldenke, Phytologia 7: 290-292. 1960; Molcenke, Biol. Abstr. 36: 719. 1961.

Additional citations: COSTA RICA: Puntarenas: Tonduz 6776 (M1-1sotype).

\title{
ADDITIONAL NOTES ON THE GENUS PRIVA. IV
}

Harold N. Moldenke

PRIVA Adans.

Additional synonyry: Tertula "Roxb. ex Willd." apud Brenan, Yem. N. Y. Bot. Gard. 9: 37, sphalm. 1954. Addittional \& emended bibijography: A. L. Juss., Ann. Mus. Nat. Hist. Nat. Paris 7: 69-72. 1806; Mirbel, Ann. Mus. Nat. Hist. Nat. Parls 15: pl. 14, fig. 2. 1810; Hook., Bot. Misc. I: 159, 172, \& 173. 1829; Peterm., Cod. Bot. Linn. Ind. Alph. 196. 1840; Endl., Cat. Hort. Acad. Vindob. 2: 47. 1843; F. Krauss, Flora 28:68. 1845; Walp. Repert. 6: 687. 1847; D. Clos, Ann. Sc1. Nat., ser. 3, 10: 378-38í. 1848; Bocq., Adansonia 2: 87-89, 94-99, 101, 109, $116,123,125,130,136,139,140,143,146-149,152$, \& 154 (1862) 
and $3: 180,182-185,211-213, \& 239-240, \mathrm{pl} .18 .1863$; Bocq., Rev. Verbenac. $87-89,94-99,101,109,116,123,125,130,136$, $139,140,142,143,146-149,152,154,180,182-185,211-213$, \& 239-240, p1. 18. 1863; Griseb., Cat. P1. Cuba 214. 1866; H. Mann, Enum. Hawri. P1. 194. 1867; Aschers. In G. Schweinf., Beitr. Fl. Aethiop. 278. 1867; R. A. Phil., Anal. Unit. Chil. 35: 193. 1870; A. Gray, Syn. FI. N. Am. 2 (1): 333 \& 334. 1878; Franchet, Sert. Somal. 50. 1882; A. S. Hitchc., Ann. Rep. Mo. Bot. Gard. 4 : 117. 1893; Just, Bot. Jahresber. 23 (2): 47, 76, \& 595. 1897; J. G. Baker in Thiselt.-Dyer, F1. Trop. Afr. 5: 285. 1900; Durand \& Jacks., Ind. Kew. Suppl. 1: 347. 1906; Reiche, FI. Chile 5: 304. 1910; ‥ Kunz, Anatom. Untersuch. Verb. 54 -55 . 1911; A. Stewart, Proc. Calif. Acad. Sc1., ser. 4, 1: 134. 1911; Ioes., Verh. Bot. Ver. Brand. 53: 80 [Abhandl. 245]. 1912; Prain, Ind. Kew. Suppl. 5: 207. 1921; Gamble, FI. Madras 1085 \& 1090-1091. 1924; Britton \& P. Wils., Scient. Surv. Porto Rico 6: 137 \& 14ل -115 . 1925; A . W. Hill, Ind. Kew. Suppl. 6: 166 (1926) and 7: 197. 1929; Baeza, Nomb. Vulg. PI. Silv., ed. 2, 63, 176, \& 263. 1930; Schwenke, Zytol. Untersuch. Verbenac. 23--26 \& 43. 1931; A. W. Hill, Ind. Kew. Suppl. 8: 194. 1933; Patermann, Beitr. Zytol. Verbenac. 2325, pl. 2, flg. 15-17, \& pl. 5, flg. 5. 1935; Chlov., Racc. Bot. Miss. Consol. Kenya 98. 1935; H. B. Davis, Life \& Works Pringle 669. 1936; A. W. Hill, Ind. Xew. Suppl. 9: 223. 1938; Robledo, Lecc. Bot. 2: 499. 19L40; Schnack, Anal. Inst. Fitotéc. Ste. Catalina 4: 18. 1942; Schnack \& Covas, Darwiniana 6: 471. 1944; Darlington \& Janaki Ammal, Chromosome Atl. 270. 1945; Hill \& Salisb., Ind. Kew. Suppl. 10: 184. 1947; Asprey \& Robbins, Ecol. Honog. 23: 411. 1953; E. J. Salisb., Ind. Kew. Suppl. 11: 203. 1953; Yoldenke, Phytologia 5: 31-32, 61-80, \& 105-111. 1954; J. Rzedowskd, Anal. Esc. Nac. Cienc. B101. 8: 105. 1954; Brenan, Mem. N. Y. Bot. Gard. 9: 37. 1954; Anon., Assoc. Etud. Tax. FI. Afr. Trop. Index 1954: 66. 1955; Anon., Trav. Lab. Bot. Syst. Brax. 16: 66. 1955; Darlington \& Wylle, Chromosome AtI., pr. 1, 323 \& 515.1955 ; YoIdenke, Verbenac. 15. 1955; Moldenke, B101. Abstr. 29: 2214 \& 2936. 1955; Moldenke in Humbert, F1. Madag. 174: 3 \& 26-33. 1956; Moldenke, Inform. Mold. Set 51 Spec. 4. 1956; Angely, Cat. Estat. Gen. Bot. Fan. 17: 5. 1956; Anon., Biol. Abstr. 29: 3469. 1957; Alain in León \& Alain, FI. Cuba 4: 280 \& 302 . 1957; B. H. Johnson, Wasmann Journ. Biol. 16: 295. 1958; G. Taylor, Ind. Kew. Suppl. 12: 174 . 1959; Moldenke, Résume 13, 28, 30, 38, 40, 42-45, $47-50,53,54,55,57-64,68,73,76-78,80,81,84,104,114$, $117,133-135,142,143,145,146,149-151,154,156,158-160$, $164,166,167,190,222,237,238,240,279,334,340,341,343$, $350,353,355,357,358,362,364-366,368-370,373,377,378$, 393-396, 407, 419, 424, 467, \& 468. 1959; Sebastine, Bull. Bot. Surv. Ind. 1: 95. 1959; Keeuse, Bothalla 7: 424-425. 1960; Angely, Liv. Gen. Bot. Bras. 35 \& 52. 1960; Anon., Assoc. Etud. Tax. F1. Afr. Trop. Index 1960: 60. 1961; Darlington \& Wylie, Chromosome Atl., pr. 2, 323 \& 515. 1961; Lewis \& Oliver, Am. Journ. Bot. 48: 64l. 1961; Runner, Rep. G. W. Groff Coll. 362. 1961; Cuf., Bull. Jard. Bot. Brwx. 32: Suppl. 794-795. 1962; Dyer, Verdoorn, Codd, \& Letty, Wild Fls. Transv. 280 1962; Hepper in Hutchinson \& 
Dalz., Fl. W. Trop. Afr., ed. 2, 2: 434-435. 1963; Rollins, Taxon 12: 215. 1963; Huber, Hepper, \& Meikle in Hutchinson \& Dalz., F1. W. Trop. Afr., ed. 2, 2: 432. 1963; H. P. Riley, Fam. Flow. P1. S. Afr. 128. 1963; Moldenke in Shreve \& Wiggins, Veg. \& FI. Son. Des. 2: 257. 1964; Punt, Reg. Veg. 36: 18. 1964; Langman, Select. Guide Lit. Flow. P1. Mex. 208, 402, 413, 515, 517, \& 1010. 1964; C. K. Allen, Bull. Torrey Bot. Club 91: 332. 1964; Moldenke, Phytologia 10: 91. 1964; Moldenke, Résumé Suppl. 11: 8 (1964) and 12: 3, 7, \& 12. 1965; Backer \& Bakh., FI. Java 2: 598599. 1965; Gooding, Loveless, \& Proctor, FI. Barbados 354, 362363, \& 481. 1965; Woldenke, Phytologia 12: 6 \& 20. 1965; Moldenke, Bol. Soc. Brot., ser. 2, 39: 131-132. 1965; Anon., Assoc. Etud. Tax. Fl. Afr. Trop. Index 1965: 67. 1966; Anon., Gen. Costa Ric. Phan. 10. 1966; G. Taylor, Ind. Kew. Suppl. 13: 18, 109, \& 149. 1966.

To be added to the list of excluded species:

Priva mitchelid Endl., Cat. Hort. Acad. Vindob. 2: 47. 1843 = Phryma leptostachya L., Phrymaceae

Riley (1963) gives the basic chromosome number for the genus Priva as 12. The Hooker (1829) reference in the bibliography above is often mis-dated "1830". The "Bot. Zeit. 3: 587 (1845)" and Flora 29: [207] (1846)" references sometimes given for this genus appear to be erroneous, since there is no mention of the gemus on those pages of the works in question.

\section{PRIVA ADHAERENS (Forsk.) Chiov.}

Additional synonymy: Verbena forskaelei Vahl ex Willd., Sp. P1. 1: 118-119. 1797. Verbena forskaehlei Vahl ex Steud., Nom. Bot., ed. 1, 657, in syn. 1821. Verbena forskohlei Vahl ex Steud., Nom. Bot., ed. 1, 873, in syn. 1821. Priva adhaerens Chiov. apud A. W. Hill, Ind. Bew. Suppl. 7: 197.1929. Priva leptostachya Auct. ex Cuf., Bull. Jard. Bot. Brux. 32: Suppl. 794 , in syn. 1962 [not P. leptostachya A. L. Juss., 1806].

Additional \& emended bibliography: Willd., Sp. PI. 1: 118$119.1797 ;$ A. I. Juss., Ann. Mus. Nat. Hist. Nat. Paris 7: 70. 1806; J. Sm. in Rees, Cycl. 36: no. 14. 1817; Steud., Nom. Bot., ed. 1, 657, 873, \& 874 (1821) and ed. 2, 2: 397 \& 750 . 1841; F. Krauss, Flora 28: 68. 1345; A. Rich., Tent. F1. Abyss. 2: 165. 1851; Bocq., Adansonia 3: [Rev. Verbenac.] 212. 1863; Aschers. in G. Schweinf., Beitr. F1. Aethiop. 1: 120. 1867; Jacks. in

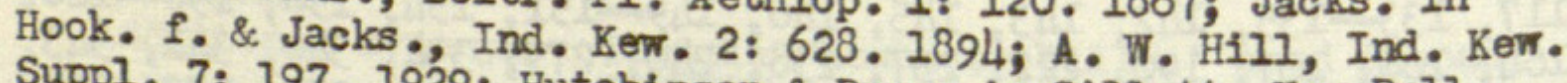
Suppl. 7: 197. 1929; Hutchinson \& Bruce in Gillett, Kew Bull. Misc. Inf. 1941: 176. 1941; Koldenke, Phytología 5: 62-63. 1954; Moldenke, Résumé 134, 135, 145, 146, 154, 158, 334, 340, $343,353,364,393$, \& 467.' 1959; Cuf., Buil. Jard. Bot. Brwx. 32: Suppl. 794. 1962; Yoldenke, Résumé Suppl. 12: 7. 1965.

Krauss (1845) cites Krauss 420 . Smith (1817) records the common name "Arabian vervain".

Additional \& emended citations: SUDAN: Lord s.n. [Upper Camp, 
Hot Tamar1b, 2/69] (Ca-331299). ANGOLA: Mossamedes: Exell \& Mendonça 2121 (UI). SOUTH AFRICA: Natal: Kuntze s.n. [Durbañ, III.94] (T-633155).

\section{PRIVA AFRICANA Moldenke}

Additional bibliography: Hill \& Salisb., Ind. Kew. Suppl. 10: 184. 1947; Moldenke, Phytologia 5: 63 \& 105. 1954: Moldenke, Inform. Hold. Set 51 Spec. 4. 1956; Moldenke, Résumé 154 \& 467. 1959.

In my 1936 work, on page 36, there is an incorrect set of figures in the Latin diagnosis of this species. The phrase should read "dentibus remotis 4 vel 5, infimis saepe subloboideis". The Van Dam s.n. [Dec. 1924] and the Codd \& Dyer 3886 specimens, cited below, were previously cited by me as being deposited in the Britton Herbarium or in my personal herbarium.

Recent collectors describe this species as a small, perennial, suffruticose plant, forming dense usually many-stemmed clumps 30 $60 \mathrm{~cm}$. tall, or a i2-inch shrublet, growing on mopane veld on limestone formations, in dry sandy Acacia thornveld in open places and shallow pans, and in open spaces in dry sparse thornveld on alkaline and probably calcareous soils, at 1800 feet altitude, blooming in March and December. The flowers are described as "pink" on Meeuse 10222, as "mauve" on L. E. Codd 3886, and as "chalk-white, rather large and striking" on keeuse 9477 .

Dr. Meeuse notes "Now that I have seen this species in the fleld, I can tell you that it is so distinct! It grows in dry deep sandy soil, probably by preference on slightly brackish soil. Flowers large, white. Other Priva species I have collected grow in light shade, have pale mauve or pinkish flowers, etc."

Additional \& emended citations: PORTUGUESE EAST AFRICA: Lourenzo Marques: Myne \& Carvalho $\mathbb{1}_{423}$ (UI). SOUTH AFRICA: Transvaal: L. E. Codd 3886 (cb, Ss); Meeuse 9477 ( $\mathrm{Z}$, , 10222 (S); Van Dam s. n. $_{.}$[Dec. 1924] (Ss).

\section{PRIVA ANGOLENSIS Moldenke}

Bibliography: Moldenke, Bol. Soc. Brot., ser. 2, 39: 131-132. 1965; Moldenke, Résumé Supp1. 12: 7. 1965; Anon., Assoc. Etud. Tax. II Afr. Trop. Index 1965: 67. 1966.

Herb, woody at the base, to $1.2 \mathrm{~m}$. tall; branches erect, tetragonal, sulcate, densely pubescent with spreading uncinate hairs, narrowed and conspicuously annulate at the nodes; leaves decussate-opposite, subsessile; petioles obsolete or to about $2 \mathrm{~mm}$. long, uncinate-pubescent; leaf-blades rotund-ovate, $4.5--5.5 \mathrm{~cm}$. long, 3--4 cm. wide, rounded in outline at the apex, rather regularly and coarsely serrate-dentate from almost the base to the apex with rather broad-based acute or rounded teeth, subtruncate at the base and abruptly acuminate or cuneate into the petiole, scattered-pilose with uncinate hairs on both surfaces, more denseIy so on the venation beneath; inflorescence terminal, racemose and spike-like, $50 \mathrm{~cm}$. long or longer, many-flowered, dense during 
anthesis, later elongating so that the fruits are separated from each other by $1-2 \mathrm{~cm} \cdot ;$ peduncle elongate, about $13 \mathrm{~cm}$. long, tetragonal, sulcate, and uncinate-pubescent like the stem and continuous with it; rachis similar to the stem and peduncle in all respects; bractlets narrowly elliptic, about $4 \mathrm{~mm}$. long, attenuate at the apex, narrowed at the base, white-ciliate on the margins with mostly stiff straight hairs; pedicels filiform, 1-2 mm. long, erect during anthesis, reflexed in fruit, densely puberulent-pubescent with brownish hairs; calyx tubular, about 7--8 m. long, densely pubescent, the rim very shallowly and inconspicuousiy 5-toothed or very shortly 5-apiculate; corolla hypocrateriform, its tube cylindric, ampliate above, about $1.2 \mathrm{~cm}$. long, white, the throat white, the limb 5-parted, the segments suffused with rose, 6 of more mm. long; stamens included; pistil about $1 \mathrm{~cm}$. long, glabrous; fruiting-calyx inflated, rotund, short-rostrate, about $8 \mathrm{~mm}$. long and $6 \mathrm{~mm}$. wide, very densely uncinate-pubescent; cocc1 tuberculate on the dorsal surface, not sping.

The type of this specles was collected by E. J. Mendes (no. 1650) at the edge of a lake opposite Rio Cunene, between Forte Roçadas and Humbe, Angola, on February 8, 1956, and is deposited in the herbarium of the Centro de Botânica da Junta de Investigaçotes do Ultramar at Iisbon. Thus far the species is known only from the type specimen.

C1tations: ANGOLA: Huila: E. J. Mendes 1650 (UI-type).

PRIVA ARMATA S. Wats.

Additional bibliography: Durand \& Jacks., Ind. Kew. Suppl. 1: 347. 1906; 1. Kunz, Anatom. Untersuch. Verb. 54. 1911; H. B. Davis, Ifife \& Works Pringle 669. 1936; Moldenke, Phytologia 5: 63. 1954; Moldenke, Résumé 38 \& 467 . 1959.

Additional \& emended citations: MEXICO: Nuevo Lebn: Pringle 1931 (Ca-104889-isotype, W-480185-isotype, W-1323168-isotype $), 2674(\mathrm{Ca}-41900, \mathrm{E}-118785)$. MOUNTED ILUUSTRATIONS: Kobuski drawing 11 (E-925406), 20 (E-925405).

PRIVA ASPERA H.B.K.

Additional bibliography: Bocq., Adansonia 3: [Rev. Verbenac.] 239. 1863; Jacks. In Hook. f. \& Jacks., Ind. Kew. 2: 628. 1894; Durand \& Jacks., Ind. Kew. Suppl. 1: $347.1906 ; \mathrm{M}_{\text {. Kunz, Anatom. }}$ Untersuch. Verb. 54. 1911; Loes., Vern. Bot. Ver. Brand. 53: 80 [Abhandl. 245]. 1912; H1ll \& Salisb, Ind. Kew. Suppl. 10: 184. 1947; Moldenke, Phytologia 5: 63-66. 195'4; Moldenke, Résumé 38, $42,45,47,222,237,340, \& 467.1959$. Recent collectors describe this plant as a bushy herb, suf-
frutescent or shrubby, $3-6$ feet tall or taller, the root heavy, woody, the stems square, dull-purple, and the fruit purple when young, becoming purplish-black when mature, growing at altitudes of 50 to 2700 meters. They have found it in loam, sandy loam, or heavy red clay-loam, by stone fences in llanos, along trails and streambanks, in vacant fields, partially grazed moist Quercus 
forests with epiphytic ferns, small rocky mixed corn-squashpotato fields and their weedy stonewall-Opuntia borders wi th Solanum bulbocastanum and a non-tuberous Solanum sp. whose berries are edible when cooked, in partial shade, on slopes with Pinus and Iiquidambar, on steep hillsides in pine forests, steep rocky slopes with Quercus, west-facing hillslopes under coffee bushes, and on steep hillsides with many moist cliffs covered with mosses in the Pimis-Quercus zone.

King refers to the species as "occasional in open grazed areas, open sun"; King \& Soderstrom call it a "common succulent annual to over 2 m. tall"; Feddema calls it "uncommon", while $\mathrm{KcVaugh}$ says that it is "abundant and weedy on barrancas"; the Wilburs refer to it as "occasional along roadsides in open oak woods".

The corollas are said to have been "pink" on Breedlove \& Raven 11933 \& 13084 , Hinton 13154 , King \& Soderstrom 4762 , and R. Mc Vaugh 12931 \& 18911 ; "lavender" on Breedlove 11837 and Feddema 709; "violet" on R. M. King 1967; "pale pink-lavender" on Tucker 786; "pale-lavender" on J. A. Steyermark 47097; "red" on Wilbur \& Wilbur 2286; and "purplish-pink, the upper lip lined reddish" on R. LeV augh 17349 .

The J. Rzedowski 6280 and Shreve 9138 , distributed as $P_{0}$ aspera, are actually P. mexicana (L.) Pers., while Mann \& Brigham 74 and Stokes s.n. [Hawaii] are Salvia occidentalls Sw. in the Lamiacese. (Ac), 11837 (Rf), 11933 (Rf); Breedlove \& Raven 13084 (AC); Seler \& Seler 2679 (w-1205554). Chihuahua: Pringle 287 (Ca-169176, $\mathrm{E}-118775, \mathrm{~W}-154992)$; Townsend \& Barber $422(\mathrm{E}-118772, \mathrm{~W}-347182)$. Guerrero: Hinton 9601 (Rf), 10687 (Rf, Ur), 11517 (Rf). Jallsco: R. McVaugh 12931 (Mi), 17349 (Mi), 20178 (Mi); Edw. Palmer 500 (W-

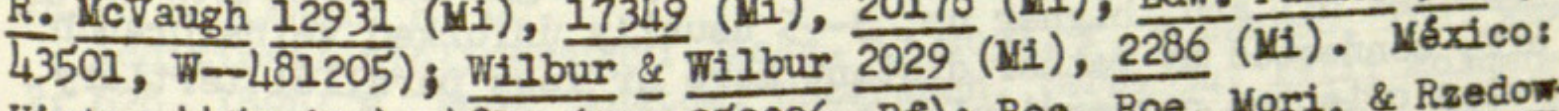
H1nton 4459 (Rf), $4 \overline{813(\mathrm{Du}-350306, \mathrm{Rf})}$; Roe, Roe, Mori, \& Rredowski 1678 (Ws). Uichoacán: Arsène 2545 (W-1003564), 2796 (B844 $844, W-1003562), 5292(\bar{E}-844852, W-1003561), 8696(\mathrm{~B}-840008$, F--485027, W--1032260), s.n. [N. O. du Punqueto, Sept. 1910] (B844842 , w-1003570), s.n. [19/9/1909] (W-1003566); Hinton 12170 (Rf), 13154 (Mi, Rf), 15625 (RP); King \& Soderstrom 4762 (N, Z); Ugent \& Flores C.2118 (Ws). Nayarit: Feddema 709 (Mi); R. HoVaugh

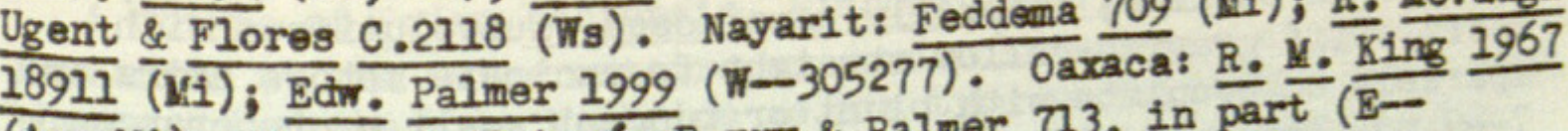
(Au, Mi). San Luis Potos1: Parry \& Palmer 713, in part (E118782). Sinaloa: Dehesa $16 \sqrt{4}(\mathrm{~W}-1035802)$. Vera Cruz: Botteri $\frac{119}{139}$ (W-771867); Bourgeau $\frac{1644}{2950}(\mathrm{Ca}-322966) ; \frac{\text { Purpus }}{1921} \frac{1925}{(\mathrm{Ca}-}$ E-825643, W--891457), s.n. [Zacuapan] (Ca-139744); Seaton 465 $(\pi-57693)$. State undetermined: Hahn s.n. [1865-66] (T-43519). GUATEasALA: AIta Verapaz: Turckheim II. $\overline{1628}$ (W-1323163, W-1323164). 
Amatitlan: Korales Ruano I.172 (F--601154). Guatemala: Rojas 64 $(W-1166629)$. Huehuetenango: Mel hus \& Goodman 3671 (0k). Sololá: J. A. Steyermark 47097 (N). Department undetermined: Heyde 206

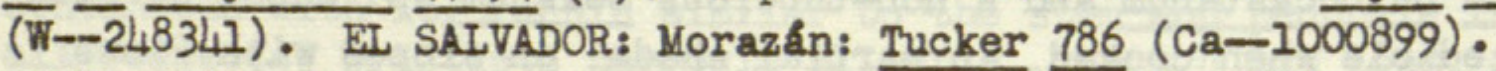

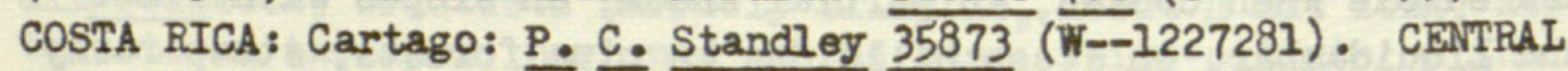
AMERICA: Locality of collection undesignated: Orsted 11183 (W-

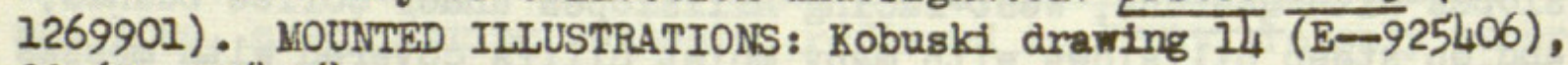
$23(\mathrm{E}-\mathrm{-925} 4 \mathrm{405})$.

\section{PRIVA AURICOCCEA Meeuse}

Bibliography: Meeuse, Bothalia 7: 424--425. 1960; Anon., Assoc. Etud. Tax. F1. Afr. Trop. Index 1960: 60. 1961; G. Taylor, Ind. Kew. Suppl. 13: 109. 1966.

A perennial herb or subshrub, about $50 \mathrm{~cm}$. tall, with a tough base, producing several erect and sparingly branched stems from the woody top of the rootstock; stems more or less distinctly tetragonal, becoming more te rete when passing into the inflorescence, rather densely leafy, short-pubescent to hirsutulous with straight or sometimes more or less distinctly uncinate hairs, the nodes marked with a narrow band of longer stiff hairs; leaves decussate-opposite; petioles to $7 \mathrm{~mm}$. long, setulose-hispidulous; leaf-blades apparently rather dark-green above, paler beneath, ovate or ovate-oblong to somewhat hastate-oblong, $2--4.5 \mathrm{~cm}$. long, $1.2-3 \mathrm{~cm}$. wide, obtuse to rounded at the apex, distinctly but usually not very deeply incised-crenate or crenate-serrate along the margins, broadiy cuneate to subtruncate at the base and abruptly narrowed into laterally decurrent wings on the petiole, subscabrid on both surfaces with fine setulose-strigose hairs slightly broadened and raised at their base; venation only conspicuous on the lower leaf-surface, indistinct on the upper; midrib rather slender, from which on either side at the base of the blade a usually unequally forked rarely single secondary vein branches off and, higher up, 3--5 usually unforked veins branch off, connected by rather distant more or less parallel tertiary veins orlented pe rpendicular to the secondary ones; inflorescence a terminal spike-like raceme, $15-25 \mathrm{~cm}$. long, the axis a direct continuation of the stem and with the same type of pubescence; pedicels ultimately $1.5-2 \mathrm{~mm}$. long, dilated at the apex into a flat disk-shaped articulation with the calyx; bractlets lanceolate, 3-- $4 \mathrm{~mm}$. long, acuminate at the apex, setulose; flowers not seen; fruiting-calyx inflated, nearly closed at the orifice, orbicular in outline, laterally compressed, subvelutinous with short stiff grayish-yellow straight to uncinate setose hairs and sparsely tuberculate with blunt or pungent small protuberances, $7--9 \mathrm{~mm}$. long and wide, 3-4 mm. thick; fruit composed of two dry 2-celled cocci (merricarps); cocci in all about $6 \mathrm{~mm}$. long, $4 \mathrm{~mm}$. wide, and $2.5 \mathrm{~mm}$. thick, spinescent with $1--2 \mathrm{~mm}$. long straight to distinctly curved spines, of a bright golden brown color, covered by a dense pubescence of minute stiff hairs, flat on the commissural surface.

The type of this species was collected by B. de Winter \& Leist- 
ner (no. 5532) at Kaokoveld, $1.6 \mathrm{~km}$. northeast of Kaoko-0tavi, on the road to Ohopoho, Southwest Africa, and is deposited in the National Herbarium at Pretoria, South Africa.

Meeuse (1960) says "Although flowers are lacking, the plant is clearly a species of Priva, a genus whose species are mostly characterized by fruit characters, the flowers being, apart from differences in size and pubescence, rather uniform in structure. In Moldenke's monograph of the genus......it would key out as $\underline{P}$. curtisiae Kobuski, an East African species, to which it is indeed closely related on account of the cocci being spiny throughout on back and sides and which it also resembles very much in habit, shape and texture of leaves, type of pubescence, 'bearded' stemnodes, etc. but from which it differs in several respects. The petioles are longer, the fruiting-calyx and cocci are larger and the spines on the cocci longer and more curved than in P. curtisiae, the calyx bears short protuberances (not found in P. curtisiae) and the fruit-cocci, which are flat on the comissural surface (not excavated as in P. curtisiae) are of a striking golden-brown colour, hence the proposed specific epithet. It is possible that more differences will be found once the flowers of $\mathrm{P}$. auricoccea have been collected. Although the differences mentioned may appear rather small, they are not smaller than those between some of the other species of long standing in the genus. In view of the urgency in connection with the preparation of the proposed Flora of South West Africa by the workers of the Botanische Staatssammlung at Munich, the description is not delayed for lack of flowers which, in this genus, are not so important for diagnostic purposes as in most other genera."

Nothing is known to me of this taxon except what is given in the original description.

PRIVA BAHIENSIS P. DC.

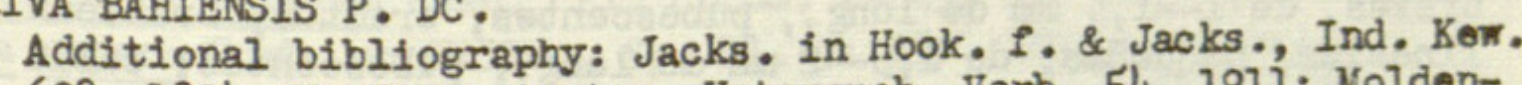
2: 628. 1894; 1 . Kunz, Anatom. Untersuch. Verb. 54. 1911; Yoldenke, Phytologia 5: 66--67. 1954; Moldenke, Résumé 104, 117, 340, \& 467. 1959 .

Recent collectors have found this plant in flower in July. Material has been misidentified and distributed in herbaria under the name Tamonea juncea Schau. The Glocker 412 collection, cited below, is a mixture with Stachytarpheta maximiliani Schau.

A cotype of Priva bahiensis, Blanchet 1027, in the Delessert Herbarium at the Conservatoire ey Jardin Botaniques at Geneva, was photographed there by Kacbride as his type photograph number 7857.

Additional \& emended citations: BRAZIL: Bahia: Blanchet 643 $(\mathrm{F}-520688), 1027$ [Hacbride photos 7857] (F-645633-cotype, $\mathrm{N}-$ photo of cotype, W--photo of cotype); A. Castellanos 25133 [Herb. Cent. Pesq. Florest. 3902] (Z); Glocker 408-13E (N), 412, in part (Bm); Salzmann 438 (E-118802-cotype). Pernambuco: Pickel 2616

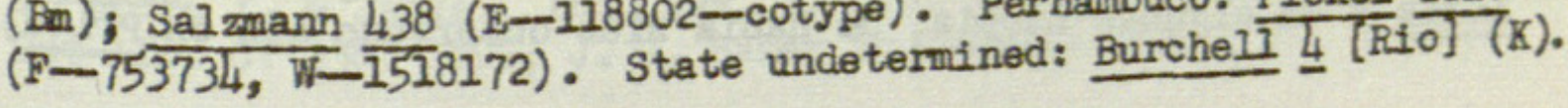


YOUNTED ILLUSTRATIONS: Kobuski drawing 9 (E-925406), 18 (E925405).

\section{PRIVA BOLIVIANA Moldenke}

Additional bibliography: E. J. Salisb., Ind. Kew. Suppl. Il: 202. 1953; Yoldenke, Phytologia 5: 67. 1954; Molcenke, Résumé 114, 117, \& 467. 1959; Troncoso, Darwiniana 11: 591-597. 1959.

Illustrations: Troncoso, Darwiniana 11: 592, 594, \& 595, fig. 1-3. 1959.

Troncoso (1959) has recently published a greatly amplified description of this species which is worth reproducing here: "Hierba perenne, pubescente, sufrutescente en la base, de 25-40 cm de alt. ( $-80 \mathrm{~cm}$, segun Koldenke), con tallos abajo ramificados, decumbente-ascendentes o suberectos, tetragonos, suavemente sulcados hacia el ápice. Ramas gráciles, densamente pubescentes con pelitos breves uncinados y pocos pelos simples rigidos particularmente sobre las aristas, glabrescentes con la edad. Entrenudos de 2-5 cm de long. Hojas opuestas, membranosas, pecioladas; lámina oval de 1,5-4 cm x 0,8-2,5 cm de long. y lat. respect., subaguda a obtusa, truncada a subtruncada, muy brevemente cuneada on la base, borde crenado, en la base entero, penninervada, nervaduras impresas en el haz, prominentes en el envés, con nervios secundarios divergentes en ángulo agudo, los dos inferiores muy aproximados, pilosa en ambas caras, epifilo con pubescencia uncinada $\mathrm{y}$ pelitos híspidos callosos en la base más densos en el borde de la lámina, hipofilo con pelitos uncinados densos y pelos más largos y rígidos particularmente sobre los nervios; pecílos surcados, de $0,5-1 \mathrm{~cm}$ de long. con pubescencia breve uncinada. Inflorescencia racimosa, racimos espiciformes de $4-10 \mathrm{~cm}$ de long. (de 8--20 segin Moldenke), superando las hojas de su propio nudo, terminales o aparentemente axilares por el crecimiento de vástagos axilares que a su vez terminan en nuevos racimos. Flores distanciadas, alternas; pedicelos muy breves, de 1-1,5 mm de long., pubescentes, erectos; brácteas lineales, pequerias, de $1,5-2$ mm de long., pubescentes; cáliz tubuloso, de 2,5-3,8 mm de long., acrescente en el fruto, ovalado-subinflado, hasta de $6 \times 3,5 \mathrm{~mm}$ de long. y lat., muchas veces hendido en dos mitades, uncinado-pubescente y con pelos largos, hispidos más ralos sobre los nervios, 5-nervado y 5dentado, con dientes muy breves, triangulares, 4 subiguales, el anterior más reducido; corola azul-violácea, pequetึa, de 5--6 $\mathrm{mm}$ de long. bilabiada, el 16 bulo anterior más reducido, bilobulado, el posterior trilobulado con el 18 bulo medio más desarrollado, 18 bulos redondeados, tubo breve apenas sobrepasando el cáliz, pubérulo exteriormente en el tercio superior, con pelitos densos retrorsos en el garganta corolar hasta la insercion de los estambres; estambres 4 , didinamos, inclusos, insertos hacia la mitad del tubo corolar, los dos superiores con una glándula conectival sésil, papilosa, rojo-vinosa, del tamafio de una teca (Este carácter de la glándula anteral, bastante común en el género Glandularia $y$ en algunas Ifppia, no habia sido observado aln en Priva), 
tecas ligeramente divergentes, filamentos breves; estilo incluso, breve; estigma bilobado con el 18 bulo anterior estigmatifero ligeramente encorvado y el posterior reducido, subdentado; ovario oval, bicarpelar con fisura central, carpelos 2-ovulados, 6vilos erectos fijos en la base. Fruto esquizocárpico, pericarpio maduro de tipo drupáceo-seco, oval-oblongo, de $2,8 \times 2,1 \times 4-5 \mathrm{~mm}$ de lat., gros. y long. respect., glabro, protegido por el cáliz acrescente, membranoso y finalmente hendido; mericarpios 2 de superficie dorsal reticulado-escrobiculada, la ventral cóncava, lisa, recubiertos por un epicarpio membranoso, brevemente dilatado en los bordes, endocarpio endurecido, marcadamente reticuladoescrobiculado dorsalmente y con $4-6$ apéndices laterales espinosos con ápice doblado hacia abajo o en forma de $T$, prolongado en la base en 3-4 phas (solamente el fruto maduro muestra el endocarpio endurecido provisto de apéndices espinosos, en el fruto immaturo es papiráceo y escrobiculado en casi toda su superficie .....), mesocarpio desvanecido dejando pequefras cavidades entre los apéndices espinosos sobre los cuales está tendido el eplcarpio como una delgada menbrana seca. Semilla exalbuminada."

Beside the type, she cites Juárez \& Burkart 20184 from Formosa, Argentina, deposited in the herbarium of the Instituto Botanica Darwinion at San Isidro, and collected in "montes xerbfilos, partes himedas".

She comments that "Priva boliviana es especie proxima a P. lappulacea (L.) Pers., tipo del género, distinguiéndose netamente por presentar esta blitima el cáliz tubular-urceolado, subtruncado en el borde, oscuramente 5-apiculado, no costillado y el fruto equinado con cortos apéndices dorsales espinosos y la superficie comisural no marginada."

\section{PRIVA CORDIFOLIA (I. f.) Druce}

Bmended synonymy: Btichnera cordifolla L. f., Suppl. 287. 1781. Streptium asperum Roxb., P1. Corom. 2: 25, pl. 146. 1798. TortuIa aspera Roxb. ex Willd., Sp. P1. 3: 359. 1801. Verbena forskaelaei Vahl ex Rottl., Gesell. Naturforsch. Freunde Berlin, Neue Schrift, 4: 222. 1803. Priva leptostachya A. I. Juss., Ann. Mus . Nat. Hist. Nat. Paris 7: 70. 1806 [not P. leptostachya Auct., 1962]. Buchnera cordifolia L. f. apud Jacks. in Hook. f. \& Jacks, Ind. Kew. 1: 350 . 1893. Priva cordifolia Druce apud A. W. Hill, Ind. Kew. Suppl. 6: 166. 1926. Verbena aspera Hitgel ex Moldenke in Fedde, Repert. Spec. Nov. 4l: 42 , in syn. 1936. Buechnerz cordifolia L. f. ex Moldenke in Fedde, Repert. Spec. Nov. 4l: 42, In syn. 1936. Tertula aspera "Roxb. ex W1lld." apud Brenan, Yean. N. Y. Bot. Gard. 9: 37, sphalm., in syn. 1954 .

Additional \& emended bibliography: A. L. Juss., Amn. Yus, Nat. Hist. Nat. Paris 7: 70. 1806; Steud., Nom. Bot,, ed. 2, 2: 397 \& 750. 1841; Bocq., Adansonia 3: [Rev. Verbenac.] 212. 1863; Jacks. in Hook. f. \& Jacks.., Ind. Kew. 2: 628. 1894; Gurke in Engl., Pfl. Ost-Afr. C: 338 . 1895; J. G. Baker in Thiselt.-Dyer, Fl. Trop. 
Afr. 5: 285. 1900; M. Kunz, Anatom. Untersuch. Verb. 55. 1911; Gamble, Fl. Madras 1091. 1924; A. W. Hill, Ind. Kew. Suppl. 6: 166. 1926; Moldenke, Phytologia 5: 67-68. 1954; Brenan, Mem. N. Y. Bot. Gard. 9: 37. 1954; Moldenke in Humbert, FI. Madag. 174: 30-33. 1956; Sebastine, Bull. Bot. Surv. Ind. 1: 95. 1959; Moldenke, Résumé $158--160,164,166,167,222,240,340,350,355$, 358, 364, \& 467. 1959; Cuf., Bull. Jard. Bot. Brux. 32: Suppl. 794. 1962; Nair \& Rehman, Bull. Nat. Bot. Gard. Lucknow 76: 8, 9, \& 23, fig. 14 a \& b, pl. 1, fig. 4. 1962; Moldenke, Phytologia 9: 40 \& 44. 1963; Punt, Reg. Veg. 36: 18. 1964.

Illustrations: Roxb., P1. Corom. 2: p1. 146. 1798; Nair \& Rehman, Bull. Nat. Bot. Gard. Lucknow $76: 9, \mathrm{flg}$. 14 a \& b, pl. 1, fig. 4. 1962.

Barnes found this plant in flower and fruit in June. Nair \& Rehman (1962) cite Nat. Bot. Gard. 12626, slide 2736, and describe the pollen as follows: " "3-zonicolporate, subprolate (47 $\mathrm{x}$ $42 \mu)$. Extocolpium slightly constricted in the middle, ends slightly rounded, margin slightly wavy. Exine thinner and forms a groove around the colpus marking a pseudocolpus, as in Verbena. Apocolpium diameter $14 \mu$. Endocolpium lalongate $(3.5 \times 14 \mu)$, dumbel-shaped being narrower in the middle and broader at the lateral ends. Exine $4.2 \mu$ thick. Ectine almost as thick as endine, granulate, adjacent granules uniting irregularly. Columella clear."

Steudel (184l) gives Verbena forskohlei Herb. Nadrid. as a synonym of what he calls Priva leptostachya, but this horticultural name actually belongs in the synonymy of $P$. adhaerens (Forsk.) Chiov. Sebastine (1959) cites his no. $\frac{1}{413}$ from India.

The Pappi 5155, distributed as P. cordifolia, is actually var. abyssinica (Jaub. \& Spach) Moldenke.

Additional \& emended citations: INDIA: Coimbatore: Narayana 1929 (Bi). Kadras: E. Barnes 1004 (G). Mysore: Ramaswany 904

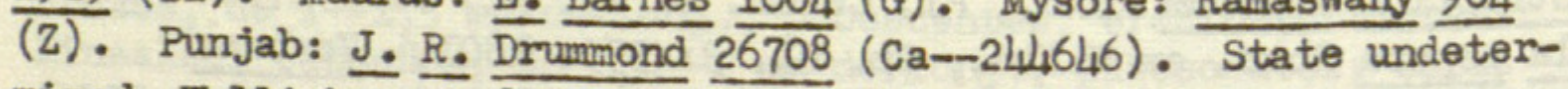
mined: Wallich s.n. [Ind. orient.] (E-119874).

PRIVA CORDIFOLIA var. ABYSSINICA (Jaub. \& Spach) Moldenke

Emended synonymy: Priva abyssinica Jaub. \& Spach, IIl. PI. Orient. 5: [57]-58, p1. 453 \& 454. 1856. Priva abessintca Jaub. \& Spach ex Briq. In Engl. \& Prantl, Nat. Pflanzenfam. 4 (3a): 153, fig. 59E, sphalm. 1895 .

Additional bibliography: Bocq., Adansonia 3: [Rev. Verbenac.] 212. 1863; Aschers, in G. Schweinf., Beitr. F1. Aethiop. 278. 1867; Franchet, Sert. Somal. 50. 1882; Jacks. In Hook. f. \& Jacks., Ind. Kem. 2: 628. 1894; Moldenke, Phytologia 5: 68-70. 1954; Brenan, Mem. N. Y. Bot. Gard. 9: 37. 1954; Moldenke in Humbert, FI. Madag. 174: 30-33. 1956; Moldenke, Résumé 133-135, $143,145,146,149-151,154,156,158,340$, \& 467.1959 ; Cuf., Bull. Jard. Bot. Brux. 32: Supp1. 794. 1962 .

IIlustrations: Jaub. \& Spach, III. P1. Orient. 5: pl. 453 \& 454. 1856; Briq. In Engl. \& Prantl, Nat. Pflanzenfam. 4 (3a): 153, 
fig. 59E. 1895.

Recent collectors describe this variety as herbaceous, erect, 2--3 feet tall, wide-spreading, the stems hollow, square, leaves pubescent, sparse, sap colorless, and calyx inflated, covered with viscid glandular hairs, growing in hard stony soil among rocks, in strand association with trees and shrubs on the inner beach, and in lowveld bush on riverbanks, at altitudes from sealevel to 1000 meters, flowering in February and July, fruiting in May.

The flowers are described as "light-blue" on Rodin 4158 , "purple with wite center" on Tanner 838, "pale-mauve, small" on I. E. Codd 5249, "pale-violet" on Humbert 14593, and "white" on

A. Peter 30334 \& 42238 .

Franchet (1882) records the plant from French Somaliland. Material has been misidentified and distributed in herbaria under the names P. leptostachya A. L. Juss. and P. meyer1 Jaub. \& Spach. On the other hand, the Mearns 2086, distributed as this variety,

is actually $P$. curtisiae Kobuski.

Additional \& emended citations: ERITPEA: Pappi 3873 (T-1969158), $5155(\mathrm{~W}--1969209)$. UGANDA: Dtmmer $30(\mathrm{~W}-633415)$; Mearns $2402(\mathrm{~W}-632375)$. TANGANYIKA: A. Peter 41007 [V.256] (B), 42238 [V.282] (B); Tanner $838(\mathrm{Ca}-182996), 1890(\mathrm{~B}, \mathrm{~S})$. KENYA: Dtmmer 4611 (W--1029976). MALAWI: J. Buchanan 887 (W-807175). PORTUGUESE EAST AFRICA: Lourenzo Marques: Rodin 4158 (Ca--302171); E. Sousa 5 (UI). Mozambique: Howard $118(\overline{W--554} \sqrt{4}+5)$. SOUTH AFRICA: Nata]: Humbert 14593 (B); A. Peter 30334 [V.11] (B). Transvaal: L. E. Codd 5249 (Z). MOUNTED ILLUSTRATIONS: Kobuski drawing $8(\mathrm{E}-925406), 17(\mathrm{E}-925405)$; Ostenmeyer drawing $153(\mathrm{~V})$.

PRIVA CORDIFOLIA var. AUSTRALIS Moldenke

Additional bibliography: Moldenke, Phytologia 5: 70-71. 1954; Noldenke, Résumé 154 \& 467.1959.

The Meeuse 9123 \& 9216, Breyer s.n. [II.1918], and Van Dam s.n. [III.1920] cited in Phytologia 5: 7 (1954) - the first two as in the H. N. Moldenke herbarium and the last two as in the Britton Herbarium -- are actually now in the Delessert Herbarium at the Conservatoire et Jardin Botaniques in Geneva.

Recent collectors have found this plant growing at 35 meters altitude and record the vernacular name "chinamene". The flowers on Torre \& Paiva 9125 are described as "white".

Additional citations: PORTUGUESE EAST AFRICA: Lourenzo Yarques: Grandvaux Barbosa \& Lemos 7869 (UI); Torre 7535 (UI). Kanica e Sofala: Torre \& Paiva 9125 (U1).

PRIVA CORDIFOLIA var. FLABETLIFORMIS Moldenke

Additional bibliography: Koldenke, Phytologia 5: 71. 1954; Brenan, Mem. N. Y. Bot. Gard. 9: 37. 1954; Moldenke, Résumé 142, 143, $145,149--151, \& 468.1959$. 
Brenan (1954) places in synonymy under this variety "Priva leptostachyz Juss. Ann. Mus. Hist. Nat. Paris 7: 70.1806, nom. illegit. cum syn. Tertula aspera Roxb. ex Willd.; Bak. in Thiselton-Dyer, F1. Trop. Afr. 5: 285. 1900, pro parte".

Recent collectors have found this plant growing in marshy meadows, at altitudes from 280 to 1290 meters, and describe it as an herb or bushy plant, 1--2 m. tall, rather spreading, with pendent flowers, blooming and fruiting in August and December. The flowers on A. Peter 10242 \& 30469 and on H. G. Faulkner 1269 are described as "white", but on H.G. Faulkner 112 as "pale-pink". Schlieben refers to the plant as "abundant".

Additional citations: TANGANYIKA: Drumnond \& Hemsley 2413 (S); H. G. Faulkner 1269 (B, S); A. Peter 75442 [0.II.I25] (B), 7988 [0. III.19] (B), 10242 [0.III.94] (B), 12475 [0.III. I54] (B), 12513 [0.III. 156 bis] (B), 12726 [0.III.I6I] (B), 13213 [0.III.IFI] (B), 15707 [0.IV.18] (B), $\overline{173 I_{4}}$ [0.IV.80] 23453 [0.IV.300] (B), $\frac{241199}{20 . I V .329]}$ (B), 18546 [0.IV.126] $\underline{51790}$ [0.IV.9] (B); Schlieben 1576 (B). RHODESIA: A. Peter 51217 [S.58] (B). PORTUGUESE EAST AFRICA: Mozambique: A. Peter $30 \overline{469}$ [V.16] (B). Quelimane: H. G. Faulkner $\underline{112}$ (S).

PRIVA CURTISIAE Kobuskd

Additional synonymy: Priva bellinil Chiov., Racc. Bot, Miss. Consol. Kenja 98, in syn. 1935.

Additional bibliography: Chiov., Race. Bot. Miss. Consol. Kenya 98. 1935; A. W. Hill, Ind. Kew. Suppl. 8: 194 (1933) and 9: 223. 1938; Yoldenke, Phytologia 5: 71-72. 1954; Loldenke, Résumé 145 , 116, \& 468. 1959; Cuf., Bull. Jard. Bot. Brux. 32: Suppl. 795. 1962.

Recent collectors have found this plant growing in grasslands and along trails, from sea-level to 5000 feet altitude, flowering in May, $\sqrt{u l y}$, August, and November, and fruiting in November. The flowers on Bogdan 352 are described as "pink", while on A. Peter 12321 they were "white". Material has been misidentified and distributed in herbaria as P. cordifolia var. abyssinica (Jaub. \& Spach) Yoldenke and as mal vaceae?"

Additional \& emended citations: KENYA: Bogdan 352 (Ca-984042); A. G. Curtis 499 (E-925409-isotype, E-925404-draxing \& photo of type); Hearns 2086 (W-632051). TANGANYIKA: A. Peter 11744 [0. III.129] (B), 12321 [0.III.149] (B), $15368(\mathrm{~B}), \overline{46863[\mathrm{~V} .314]}(\mathrm{B})$.

PRIVA DOMINGENSIS Urb.

Additional bibliography: Prain, Ind. Kew. Suppl. 5: 207. 1921; Moldenke, Phytologia 5: 72. 1954; Moldenke, Résumé 57 \& 468.1959. This species is known to ascend to an altitude of at least 800 meters in the Dominican Republic.

Fmended citations: HISPANIOIA: Dominican Republic: Elman H. 5842 (W-1410114); Valeur $186(\mathrm{~W}-1 /, 14656)$. Harti: Leonard \& Leon- 
ard $12775(\mathrm{Ca}-440448), 13037(\mathrm{~W}-1451726), 13597(\mathrm{~W}-1452228)$, 13795 (E-992257, W--1452388).

PRIVA GRANDIFIORA (Ort.) Moldenke

Additional synonymy: Priva rhinanthifolla B: L. Robinson apud A. W. Hill, Ind. Kew. Suppl. 8: 194. 1933. Priva grandiflora Moldenke ex J. Rzedowski, Anal. Esc. Nac. Cienc. Biol. 8: 105. 1954. Priva rhínanthifolia (M. \& G.) Greenm., in herb.

Additional bibliography: Walp., Repert. 6: 687. 1847; Jacks. in Hook. f. \& Jacks., Ind. Kew. 2: 628. 1894; M. Kunz, Anatom. Untersuch. Verb. 55. 1921; Perry, Ann. Mo. Bot. Gard. 20: 342 \& 355. 1933; A. W. Hill, Ind. Kew. Suppl. 8: 194. 1933; Schnack, Anal. Inst. Fitotéc. Sta. Catalina 4: 18. 1942; Schnack \& Covas, Darwiniana 6: 471. 1944; Darlington \& Janakd Ammal, Chromosome Atl. 270. 1945; E. J. Salisb., Ind. Kem. Suppl. Il: 202. 1953; J. Rzedowsld, Anal. Esc. Nac. Cienc. Biol. 8: 105. 1954; Koldenke, Phytologia 5: 72-73.(1954) and 6: 239. 1958; Moldenke, Résumé $38,222,340,347,355,365,373,377$, \& 468. 1959; Noldenke, Phytologia 8: 183, 427, \& 4,47 (1962) and 9: $307 \& 315.1963$.

Recent collectors have found this plant growing in grass by cornfields, in grasslands with scattered pines or stony outcrops, in roadside ditches through the desert, in pedregal, and in dry rocky level grazed Acacia-Hilaria-Aristida-Opuntia grasslands with many herbs like Calochortus, Ruellia, 0xal1s, Artemisia, Salvia, Mimulus, etc.; also on stony hillsides, mesquite-nopal savannas, gentle slopes on reddish sandy loam, and flat mountain tops, and munder oaken hills", at altitudes of 2000 to 2665 meters. Hinton describes the plant as "procumbent", while Haterfall notes "roots fascicled".

The corolla is described as "pale-lavender and white blotched" on Wointraub \& Roller 173, "lavender" on Hinton 13204, "lightpink" on Waterfall 13400, and "pale-bluish, nearly white" on R. McVaugh 18278. Schnack \& Covas (1944) report the chromosome number as $2 n=10$.

Material has been misidentiffed and distributed in herbaria

as Acalypha sp., Valerianodes sp., and Verbena sp.

Additional \& emended citations: UExICO: Aguascalientes: R. Mc

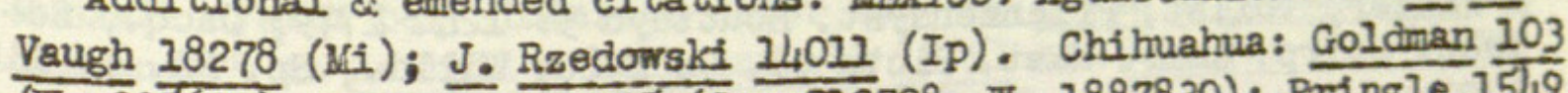

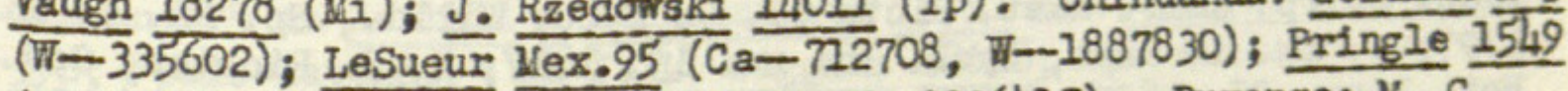

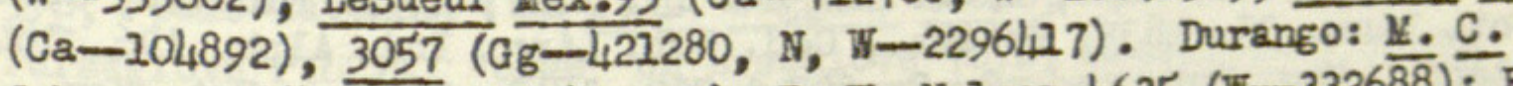
Johnston 2664 (Au-231742, N1); E. W. Nelson $4635($ W- 332688$) ;$ Edw.

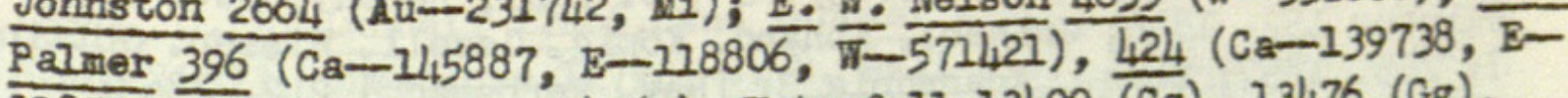
$\left.118770, \frac{39}{E}-118771, \mathrm{~W}-304369\right)$; Waterfall $\left.13400 \mathrm{(Gg}\right), 13476$ (Gg), 15433 (Gg), 16158 (Ca); Waterfall \& Wallis 13358a (St), 13400 (St),

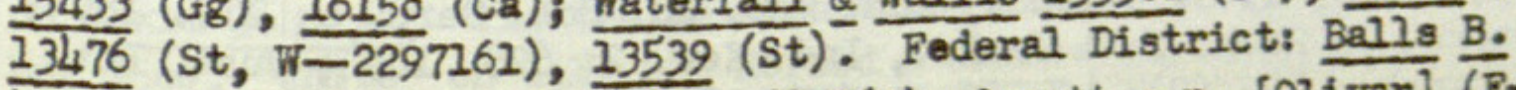
$4923(\mathrm{Ca}-684 \mathrm{12} 28), \mathrm{B} .5665(\mathrm{Ca}-683963)$; Orcutt s.n. [01ivar] $\overline{(\mathrm{F}}-$ 281902); Rose, Fainter, \& Rose 8511 (W-L52003), 9496 (W-452987).

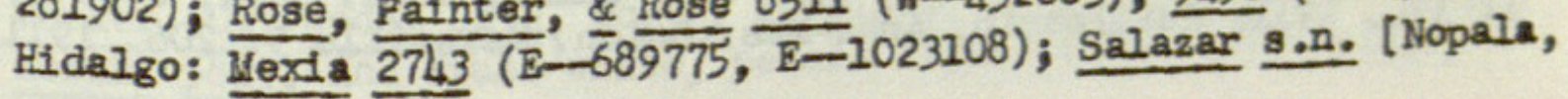


Aug. 1, 1913] (W--1169845). Jalisco: J. N. Rose 3576 (W-302553); Weintraub \& Roller 173 (Mi). México: Bourgeau 357 (W-209558);

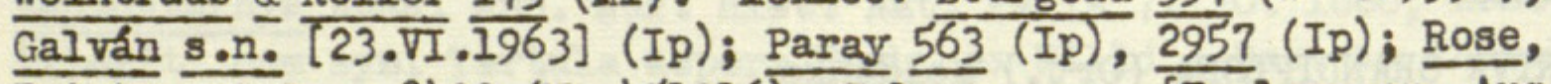
Painter, \& Rose 8422 (T--451916); Salazar s.n. [Teoloyucan, Aug. 11, 1913] (W-1013206, W-1169846). Wichoacán: Arsène 3499 (W-1003701), 8296 (E-841342, W-1003669); Hinton 13204 (Ni, Rf, Ur, W-1891048); IItis, Koeppen, \& Iltis 530 (S); Pringle 4747 (Ca25126, E-118769, $1 \mathrm{~m}-15406, \overline{\mathrm{W}}-57689, \mathrm{~W}-14 \mathrm{1} 8001$ ) CULTIVATED: Germany: Herb. Bernhardi s.n. [Hanover] (E-118048). NOUNTED ILLUSTRATIONS: Kobuski draxing 13 (E-925406), 22 (E-925405).

\section{PRIVA HUAIBERTI Moldenke}

Additional bibllography: Moldenke, Phytologia 5: 73. 1954; Molcienke in Humbert, FI. Madag. 174: 28-29. 1956; Molcenke, R6sumé 156 \& 468. 1959; G. Taylor, Ind. Kew. Suppl. 12: 114. 1959.

\section{PRIVA LACINIATA Moldenke}

Additional bibliography: Hill \& Salisb., Ind. Kew. Suppl. 10: 184. 1947; Moldenke, Résumé 64 \& 468. 1959.

\section{PRIVA IAPPULACEA (I.) Pers.}

Additional \& emended synonymy: Priva echinata A. L. Juss., Ann. Yus. Nat. Hist. Nat. Paris $7: 69.1806$. Verbena tetrandra, calyc. subrotundis erectiusc., sem. echinatis $\bar{L}$. apud $\mathrm{H}$. E. RAchter, Cod. Bot. Linn. 35. 1835. Blairia Houst. apud H. E. Richter, Cod. Bot. Linn. 35, in syn. 1835. Scorodonia floribus spicatis purpurascentibus pentapetaloidibus Sloane apud H. E. Richter, Cod. Bot. Linn. 35, in syn. 1835. Priva lappulacea Pers. ex Benth., Bot. Voy. Sulphur 152. 1846. Priva lapulacea I. ex Patermann, Beitr. Zytol. Verbenac. 23 \& 24 , sphalm. 1935. Blairla "Houst. ex Adans." apud G. Taylor, Ind. Kew. Suppl. 13: I19, in syn. 1966. Privia lappulacea (I.) Pers., in herb.

Additional \& emended bibliography: L., Syst. Nat., ed. 10, 852. 1759; Adans., Fam. PI. 2: 198. 1763; Jacq., Obs. Bot. 1: 37, pl. 24. 1764; J. A. Nurr. in I., Syst. Veg., ed. 13, 62. 1774; Christm. \& Panzer, Vollst. Pflanzensyst. Houttuyn 5: 124. 1779; Jacq., Select. Stirp. Amer. Hist. Plcta pl. 9. 1780; Willd., Sp. Pl. 1: 118. 1797; J. Sm. in Rees, Cycl. 36: no. 13. 1817; H. E. Richter, Cod. Bot. Iinn. 35. 1835; Peterm., Cod. Bot. Iinn. Ind. Alph. 196. 1840; Steud., Nom. Bot., ed. 2, 2: 397 \& 750. 184l; Benth., Bot. Voy. Sulphur 152. 1846; Griseb., Abhand. KOnig. Gesell. Wissen. Gutting. 7: 255. 1857; Bocq., Adansonia 3: [Rev. Verbenac.] 212. 1863; Griseb., Cat. PI. Cuba 214. 1866; A. Gray, Syn. FI. N. Am. 2 (I): 334. 1878; A. S. Hitche., Ann. Rep. Mo. Bot. Gard. 4: 117. 1893; Jacks. In Hook. $f_{0}$ \& Jacks., Ind. Kew. 2: 628. 1894; Just, Bot. Jahresber. 23 (2): 47,76, \& 595. 1897; 4. Kunz, Anatom. Untersuch. Verb. 54 \& 55. 1911; A. Stewart, Proc. Calif. Acad. Sc1., ser. 4, 1: 134. 1911; Guillaumin, Ann. Mus. Colon. Marseille 9: 206. 1911; 
Loes., Verh. Bot. Ver. Brand. 53: 80 [Abhandl. 245]. 1912; Stapf, Ind. Lond. 6: 430. 1931; Schwenke, 2ytol. Untersuch. Verbenac. 23-26 \& 43. 1931; Patermann, Beitr. Zytol. Verbenac. 23-25, 43, 48 , [54], \& [56], pl. 2, fig. 15-17, \& pl. 5, fig. 5. 1935; Robledo, Lecc. Bot. 2: 499. 1940; E. J. Salisb., Ind. Kew. Suppl. 10: 33. 1947; Brayo Hollis \& Ramirez Cantu, Anal. Inst. Biol. Mex. 22: 421. 1951; Asprey \& Robbins, Ecol. Monog. 23: 471. 1953; Moldenke, Phytologia 5: 95 \& 105-106. 1954; Darlington \& Wylie, Chromosome AtI., pr. 1, 323. 1955; Moldenke, Yem. N. Y. Bot. Gard. 9: 177. 1955; Bravo Hollis, Anal. Inst. B10l. Mex. 26: 297. 1955; Koldenke, Verb. 16-17. 1955; Alain in León \& Alain, Fl. Cuba L: 302, fig. 130a. 1957; B. H. Johnson, Wasmann Journ. B101. 16: 295. 1958; Koldenke, R6sume $13,28,38,40,42-45,47-50,52,54$, $55,57-64,68,73,76-78,80,81,84,104,174,190,222,237$, $238,240,340,343,353,355,364,366,368-370,378,394, \& 468$. 1959; Darlington \& Wylie, Chromosome At1., pr. 2, 323. 1961; Hepper in Hutchinson \& Dalz., F1. W. Trop. Afr., ed. 2, 2: 434-435. 1963; Moldenke in Shreve \& Wiggins, Veg. \& FI. Son. Des. 2: 1257. 1964; Moldenke, Résumé Suppl. II: 8. 1964; Gooding, Loveless, \& Proctor, F1. Barbados 362-363 \& 481. 1965; Backer \& Bakh., F1. Java 2: 599 . 1965; G. Taylor, Ind. Kew. Suppl. 13: 18 \& 149. 1966.

Additional illustrations: Jacq., Obs. Bot. 1: 37, pl. 24. 1764; Jacq., Select. Stirp. Amer. Hist. Picta pl. 9. 1780; Patermann, Beitr. Zytol. Verbenac. pl. 2, fig. 15-17, \& pl. 5, fig. 5. 1935; Alain in León \& Alain, Fl. Cuba L: fig. 130a. 1957.

Recent collectors describe this plant as an annual or perennial herb, erect or decumbent, to $1 \mathrm{~m}$. tall, with a large taproot, small or mimute flowers, the calyx green and inflated, the anthers yellow or pale-yeilow to tan or brown or even white, the stigmas yellowish, the ovary green, and the fruits green, 4partite, and very adhesive. The fiovers are described as "purple" on Heraid \& Clark 406 and Hinton 16120, "Iight-purple" on H. H. Bartlett $121 \overline{62}$ and J. V. Santos 2221, "purplish" on Abbott 429 , "pale-purple" on Woytkowskd 5618, "purple-lavender, white-streaked in throat \& on Iobes" on B. I. Turner 2100, "violet" on Hinton 1967, "pale-violet" on Kolina R. 263, "light-violet, $8.5 \mathrm{p} 4 / 9$ on Nunsell system per Nickerson color fan" on Straw \& Forman 1838, "lavender" on Correll \& Schweinfurth 15651 and Wiggins \& Rollins 396, "pale-lavender" on I. L. Wiggins 18628, "pale-mauve" on Furseglove P.622I, "blue" on Breedlove 7670 , Breedlove \& Raven 13347, C. L. Lundell 12466, and Tuncker 17028, "pale-blue" on AspIund 15373 , Breedlove 11793 , J. B. Hall 2517, Irwin R.117, and Morton 5441, "pink" on Glassman 1715 and Koelz 34220, "crimson" on Kexaa 364 1/2, "lightwblue wh thite center" on Wilbur \& Wilbur 1569, "white" on Goll 28, Herald \& Clark 339, H4nton 1229, R. M. King 747 , D. A. Iima 53-1294, Yorley 794, Ryan \& Floyed 79, Tucker 501, Wedel 2834, Worth, Norrison, \& Horton 8611 , and Woytkowski 5617, and "tube white, petals light-violet" on Crosby, 
Vol. 14, no. 6

Hespenheide, \& Anderson 95 .

This is a widespread species, found from southern Florida and southeastern Texas through the West Indies and Central America south to eastern Peru and Bolivia; introduced in Java and Ghana; occasionally cultivated elsewhere.

Recent collectors have found it growing in shaded areas, open or flat grazed areas, in loam soil, clay, or silty-clay soil, in alpine meadows, dry arroyos, pedregal, Prosopis brush, fields, barrancas, secondary matorral, and in dense woods composed of woody Mimosaceae, Cereus-type cacti, araliads, etc., 6-10 m. tall, along or near roadsides, sandy roadsides, and stream bottoms in shady canyons, bordering thickets, and adjacent to ditches, as well as on dry slopes and in coffee plantations, from near sea-level to 1600 meters altitude.

Schwenke (1931) reports the haploid chromosome number as 6. Additional common names reported for the plant are "bur vervain" and "farolito". It has been collected on clay flats, open rocky clay hillsides, wooded slopes, wooded creek banks, cliffs, shaded sandy slopes and steep northeast slopes among rocky outcrops, in rocky clay soil, rocky clay-loam, volcanic soil with humus, wet alluvial clay, calcareous clay-loam, and limey soil with rocks, in deep or partial shade, woods, waste land, hedgerows around fields, swamps in low wet palm areas, pastures, varied short brush on hills, and in sand and limestone rocks in the mountains.

Worth, Lorrison, \& Horton describe the style as "gynobasic", which is a characteristic of the Lamiaceae. Herald \& Clark refer to the plant as a "I ft. subwoody herb" and say that its habitat is "riparian"; Wedel calls it a "shrub $21 / 2 \mathrm{ft}$. tall" and Chagas refers to $1 \mathrm{t}$ as "arbusto" $1 \mathrm{~m}$. tall. These are all probably errors in observation. Crosby, Hespenheide, \& Anderson report the species as "common" in Jamaica, where Yuncker refers to it as a "waste area weed". My son, Andren R. Moldenke, reports it to be a "common weed" in Costa Rica. The Wilburs refer to it as "very common in disturbed areas" in Jalisco; King reports it as both "uncommon" in shaded areas and in partial shade, "common" "growing in gravelly loam in open sun", "occasional in open sun", and "uncoumon" in Oaxaca. Feddema describes it as "occasional in sandy loam, partial shade, of old fields and hedgerows" in Nayarit; Ryan \& Floyed found it "abundant" in Guerrero; Graham \& Johnston call it an "infrequent annual weed" or even "very rare" in Tamaulipas; Sauer found it "behind spray zone on broken limestone coralline bench" in Jamaica; while Correll \& Johnston report "only a couple of plants seen, RARE, at edge of road in palm harmock" in Cameron County, Texas. On the Galapagos Islands it is said to grow in the Scalesia zone and in dense jungles of the Upper Transition zone with P1sonia trees.

In Shreve \& Wiggins (1964) the distribution of this species is given as "In thickets and weedy flats, along small arroyos, and on canyon floors; common as a weed in clearings and along streets, Sonoran to Tropical zones, from Florida and Texas through the West Indies, Mexico, and Central America to Peru, Brazil, and Bolivia; 
naturalized in Java. Occurring in the Sonoran Desert near Matape, about 40 miles northeast of Hermosillo, Sonora."

Hepper (1963) calls the plant "A perennial weed with spreading and decumbent or erect stems, markediy 4-angled; flowers small, the corolla violet with paler stripes." He cites Hall 1891 from Asebu, near Cape coast, in Ghana, and notes "A native of the warmer parts of America and the West Indies; introduced into Java and possibly elsewhere, but not previously recorded from Africa." Backer \& Bakhuizen van den Brink (1965) affirm that it is truly naturalized near Bantur, Java, flowering there all through the year, along roadsides at about 300 meters altitude, and that "In detached branches the corolla is very easily shed (traumatochory); when the fruit is mature the calyx (with the enclosed fruit) comes off from the persistent pedicel and easily clings to passing objects by the aid of upcurved bristles."

The description of this plant by Linnaeus, as given by J. A. Nurray $(1774)$, is worth repeating here:

lappulacea. 7. V. tetrandra, calyc. subrotundis erectiusculis, sem. echinatis. Jacq. obs. $37, t .24$. Burseria Loefl. 1t. 194. n. 69. Semina bilocularia sunt.

In the Linnean Herbarium, under genus 35, Verbena, specimen number "5" is labeled "lappulacea" in the handwriting of Solander and bears the notation "Br". It is definitely what we now understand as Priva lappulacea (L.) Pers. Specimen number "6", pinned to number " 5 ", is labeled "lappulacea" in Linnaeus' on handwriting and also bears the notation "Br." [=Brome] and "Rolander" [Rolander collected in Surinam after 1754 ]. It is Salvia occidentalis $\mathrm{S}$. in the Lamiaceae.

It should be noted here that the C. Junge 2993 collection, cited below, bears a label inscribed "PLANTS OF CHILE", but was actually collected in the Dominican Republic!

Material of Priva lappulacea has been misidentified and distributed in herbaria as P. aspera H.B.K. and as P. mexdcana (L.) Pers. On the other hand, the Tucker 786, distributed as P. lappulacea, is actually P. aspera H.E.K.; F. W. Gould 10810 is P. mexicana (L.) Pers.; (Gill. \& Hook.) Troncoso; and J. Rzedowskd 19977 and I. L. Wiggins 18810 are probably mints.

Additional \& emended citations: FLORIDA: Monroe Co.: Blodgett s.n. [Key West] (W--43516); Duckett s.n. [June 17, 1930] (W1485601); Garber s.n. [Key West, Aug. 1877] (W-43518); H. N. Yoldenke 614 $(\mathrm{E}-1002894, \mathrm{~W}-1581810)$; Edw. Palmer 395 (E-118768, F-266379, W-43517); Rugel s.n. [Florida, 1842-1849] (E-116954, W-512596). TEXAS: Cameron Co.: Correll \& Johnston 17948 (Rf); C. L. Lundell 12466 (RP); R. Runyon 562 (W-12 243499$)$. Hidalgo Co.: Correll \& Schweinfurth $156 \overline{51(\mathrm{Rf})}$. MEXICO: Baja California: T. S. Brandegee s.n. [Corral Piedra] (Ca-104890), s.n. [San Jose del 
Cabo] (Ca-104891, W-40072). Campeche: Goldman 458 (W--396821); C. I. Lundell 883 ( $\mathrm{Ca}-486969, \mathrm{E}-101704 \mathrm{I}, \mathrm{F}-700492$, W1494515); C. D. Mell 2061 (W--1588308). Chiapas: Breedlove 7670 (Du-508668), $\overline{1} \overline{793}(\overline{\mathrm{Rf}) \text {; }}$ Breedlove \& Raven $13347 \overline{(\mathrm{AC}) \text {. Colima: }}$ P. Golcosmith 89(Ca-923500, Du-349897); Koelz 34220 (Mi); Edw. Palmer 1007 (W-209151); Worth, Norrison, \& Horton 8611 (Ca643505). Guerrero: R. Q. Abbott 429 (Ip); Barkley, Webster, \& Paxson 17 1739 (Au-123212, Au-209670); Herald \& Clark 339 (Ui) 406 (Mi); Hinton 10545 (Rf), 10573 (Rf), 14391 (Rf); Lyonnet 483 (T-1034282); Edw. Palmer 551 (Ca-167893, E-118781, W-267026); Pargy 3039 (Ip); Rose, Painter, \& Rose 9419 (W-452907); Ryan \& Floyed 79 (Mi); Willis \& Crisman 239 (Mi). Hidalgo: Lundell \& Lundell 12382 (Rf). Jalisco: Wilbur \& Wilbur 1569 (Ni). Néxico: Hinton 4360 (Rf); Ortonburger, Paxson, \& Barkley 16M816 (Ca-

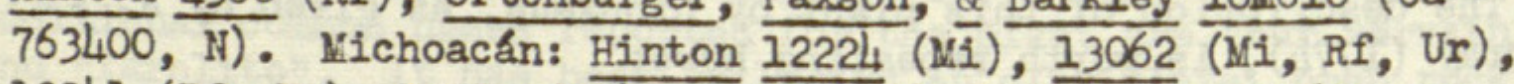
13947 (Rf, Ur), 13970 (Rf), $13975(\mathrm{Rf}), 16120(\mathrm{Ca}-97622, \mathrm{Mi}, \mathrm{N})$; B. L. Turner 2100 (Mi). Nayarit: Feddema 529 (Mi); Ferris 5643

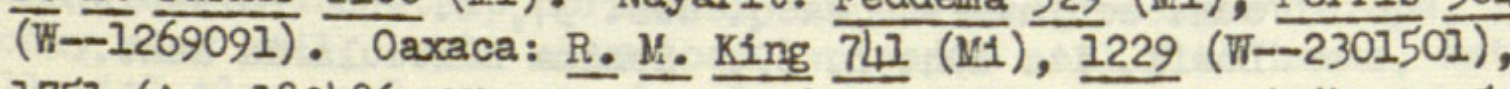
1751 (Au-183486, $\mathrm{Ni}, \mathrm{N}, \mathrm{W}=2301521), 1967(\mathrm{~W}-2301525), 1995$ (Au, Mi, W-2301527); Martinez-Calderon 227 (Rf). Quintana Roo: G. F. Gaumer 1702 (B, E-952970, F-58500, W-1267424), 1702 bis $\overline{(D}-\overline{6} 5 \overline{8347)}$. San Luis Potos1: J. Rzedowski 10366 (IP). Tinaloa: T. S. Brandegee s.n. [Culiacan] (Ca-104893, $\frac{}{W-873701) ; ~ G o n z a l e z ~}$ Ortega $4220(\mathrm{~W}-1083506), 6429$ (D-651101), 6758 (F-709231); Mexda 364 I/2 (Ca-367533, E-966856); Nervaez Yontes \& Salazar 389 (W-1035275); Edw. Palmer 1458 (Ca-770289, F-707669), 吕, in part (W-305280); J. N. Rose $1722(W-300588)$, 3240 (W-302205); Rose, Standley, \& Russell 13371 (T-636195), 13711 (W-636540); J. Rzedowshd 16547 (Ip); Straw \& Forman 1838 (Mi). Sonora: Wiggins \& Rollins 396 (Vi); Edw. Palmer 745 (W-57692). Tabasco: Rovirosa 531 (Ca-251125, W-1323167). Tamaulipas: Graham \& Johnston $468 \mathrm{lh}(\mathrm{Au}-174345), 4683 \mathrm{a}$ (Au-174698, Mi); Edw. Palmer $8(\mathrm{E}-777475, \mathrm{~W}-462944), 502$ (W-572731). Vera Cruz: Barkley, Rowell, \& Webster 2640 (Au=-123208); Mohr s.n. (W--771822); Or-

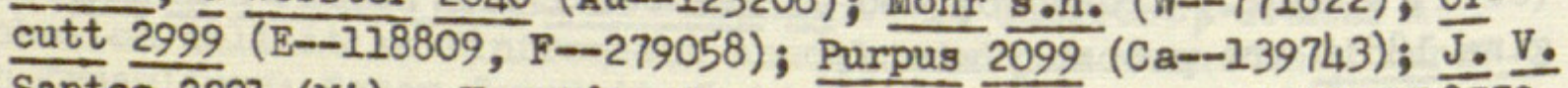
Santos 2221 (Mi). Yucatán: G. F. Gaumer $\frac{2099}{364}$, in part (E-118779, F-361 $6 \overline{7, W}-268669)$, 394, in part $\frac{\text { F }}{(F-36197)}, 24029(F-552031$, W-1268127), s.n. [IzamaI, 1888] (F-181636), s.n. [Buena Vista] $(\mathrm{F}-187330)$; Gaumer \& sons $1702\left(\mathrm{Ca}-4 \mathrm{~L}_{4} 6012\right) ; \frac{\text { s.n. }}{\mathrm{C} . \bar{F} \text {. Mill spaugh }}$ $1548(\mathrm{~F}-61548) ;$ Schott 22 (F-40020), 23 (F-40021); Seler \& Se$\left.\frac{1 e r}{221} \frac{3995}{787}(\mathrm{~F}-1) \mathrm{H}_{4} 544\right)$. GUATEMALA: Alta Verapaz: Goll 28 (W2215787); H. Johnson 211 (W-1081323). El Petén: $\mathrm{H}_{0}$ H. Bartlett

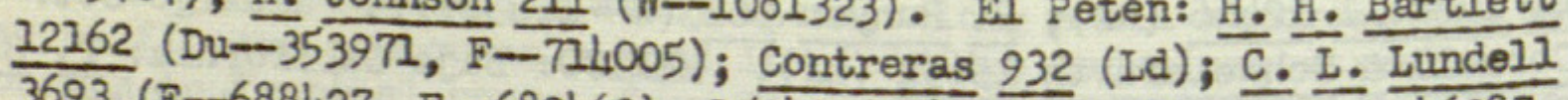
$\underline{3693}(\mathrm{~F}-688427, \mathrm{~F}-689469), \underline{15343}$ (Ld); $\frac{932}{\mathrm{~J}}$ A. Steyermark 46287 
(Mi, Rf). Esciintla: Rojas 77 (W- 1166665$)$. Izabal: Greenman \& Greenman 5978 (E-908315); P. C. Standley 23762 (W--1139437), 24635 (W--1150256), 24795 (W-1150413). Santa Rosa: Heyde \& Lux $3017(W-57691, W-1323161)$. Solola: Shannon $247(\mathrm{~W}-\overline{43507}$, W1323166). BRITISH HONDURAS: Gentle $17 \overline{4(F-713008)}$; Karling 42 (F-599844, W-1406569); C. L. Lunde11 79 (F-597989), 363 (F712069); W. C. Meyer 139 (F-713297); schipp 845 (Ca-481631, E1020212, F-712431). HONDURAS: Atlántida: Severen 25 (W-1168299); P. C. Standley $53649(\mathrm{~W}-1407865)$. Cortés: Thieme 775 [J. D. Smith 5613] (W-1323165). La Union: Morrison \& Beetle 8770 (Ca643529). Morazán: Glassman 1715 (N, Ok, Ur); Molina R. $\overline{263}$ (Ca-792806). EL SALVADOR: Ahuachapán: P. C. Standley 1974 $1135644)$. La Libertad: P. C. Standley $23339(\mathbb{W}-1139028)$. Morazán: Tucker 501 ( $\mathrm{Ca}-1000902, \mathrm{Mi}, \mathrm{N}, \mathrm{Rf}, \mathrm{Vi})$. San Miguel: P. C. Standley 211 II (W-1136927). San Salvador: Calderbn 917 (T1151880); Renson 146 (W-576119); Velasco 8854 (W-829126, W1323156). Sonsonate: P. C. Standley 21905 (W-1137660), 22003 $(W--1137758), 22097$ (W-1137846). NICARAGUA: Chinandega: C. F. Baker 754 (W-862823); Maxon, Harvey, \& Valentine 7106 (W1180820). Grenada: C. F. Baker 166 (Ca-199144, E-808110), 619 (IT-862715); Maxon, Harvey, \& Valentine 7601 (W-1181311). Managua: Artemio $49(\mathrm{~W}-1206387)$; Chaves $310(\mathrm{~F}-599800)$; Maxon, Harvey, \& Valentine 7329 (W-118104I); Morley 744 (Ca-756782); René 66 (W-1209830). COSTA RICA: Alajuela: A. R. Moldenke 1204 (Rf). Guanacaste: A. R. Moldenke 1215 (Ac). Limbn: United Fruit Co. 71 (W-861477). Puntarenas: J. A. Echeverria 4184 (Ca-

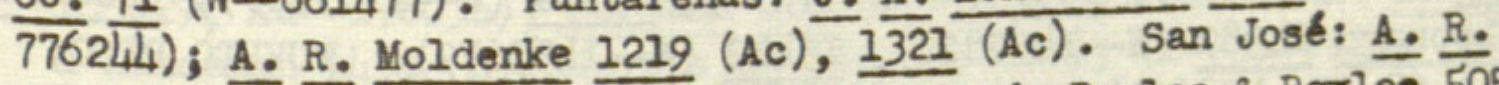

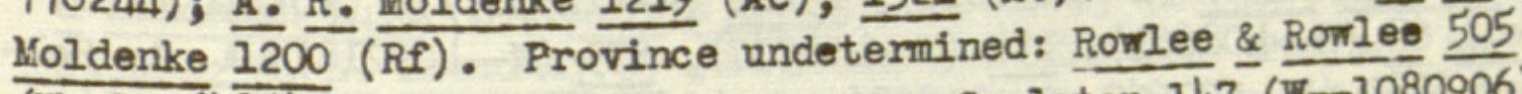
(W-10364 86$)$. PANAMA: Bocas del Toro: Carleton 147 (W-1080906); C. P. Cooper $129(\mathrm{~F}-579557)$; Dunlap $19 \overline{(W-1205126) ; ~ H . ~ v o n ~}$

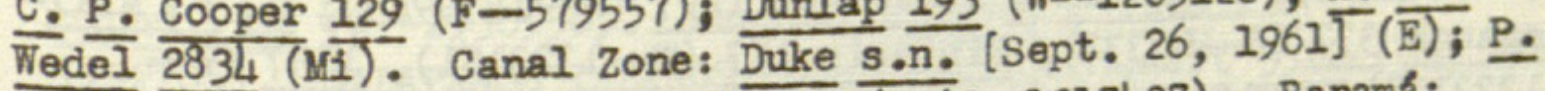
C. Standley $26473(\mathbb{W}-1217023), 27157$ (W-1217427). Panamá: Killip 12003 (W-1167139); P. C. Standley 2891.6 (W-1218387); R. S. Williams $1032(W-678365)$. PEARL ISLANDS: Killip 3178 (T863165); H. Pittier 3560 (W-678616); P. C. Standley 27031 (W$1217340), \overline{2} 7 \overline{917}(\mathrm{~W}-112784 \mathrm{4})$. BAHAMA ISLANDS: Andros: SmaIl \& Carter $892 \overline{8}(\mathrm{~W}-758229)$. Eleuthera: Britton \& Millspaugh 5534 (N); A. S. Hitchcock s.n. [11-18-90] (E-120202). Green Turtle: Brace $\frac{14}{82} \frac{1}{(N) \text {. New Providence: Brace } 23}(\mathrm{~F}-248455)$, 95 (N), $483(\mathrm{~K})$; Britton \& Brace $534(\mathrm{~N}), 655(\mathrm{~N})$; Curtis 244 (B-118787, W-428524); Earle $12(\mathrm{~N}) ;$ A. E. Wight $40(\mathrm{~F}-225221, \mathrm{~N})$. Parrot: Millspaugh \& Millspaugh $91 \overline{96}(\mathrm{~N})$. Watiing: Britton \& Millspaugh $6166(\mathrm{~N})$. Island undetermined: A. S. Hitchcock s.n. $[\overline{12-3-90]}$ 
(E--46910). CUBA: Havana: Leb́n s.n. [15-5-1909] (Vi), s.n. (Vi4027); Van Hermann 113 (E- $\overline{969555, \mathrm{~F}}-170529$ ). Las Villas: Combs 220 (E-118796, F-358024); Pringle 9 (W--428424). Matanzas: Eggers 5274 (T-1323162). Oriente: Alain 1992 (Z); Hioram \& Btiste $\frac{1323}{132}($ Um--100); C. F. Millspaugh 1043 (F-61043), 10L8 (F61048); Morton \& Alain 9013 (W--2285127); Shafer 1576 (Bi, W659811). Pinar del Rfo: Shafer 11144 (W-699300). CAYMAN ISLANDS: Grand Cayman: A. S. Hitcheock s.n. [Jan. 1890] (E--118795); C. F. Mill spaugh $128 \overline{6}(\bar{F}-61286)$. JAMAICA: R. C. Alexander s.n. [Rio Cobre] (F-504988), s.n. (W-1048225); S. Brown $306(D-538924)$; Crosby, Hespenheide, \& Anderson 95 (Mi); Fredholm 3081 (W-315932); W. Harris 11796 (E-792594, W-790858); A. S. Hi tchcock s.n. [129-190] (E-118794); H. A. Lang 61 (D-554717), 62 (D-554761); Lloyd 1004 (E-118793, F- 228293); Naxon 1657 (W--427952), 2180 (W-520088); Maxon \& Killip 313 (W--1046009), 1605 (W-1046615); C. F. Nill spaugh $921 \overline{(F-60921)}, 1910$ (F-87523); Orcutt 1943 (Ca-430599), $2276(\mathrm{Ca}-430600) ; \frac{\mathrm{F} . \mathrm{W} .}{\mathrm{Fennell}} 11225(\mathrm{D}-645442)$; Sauer 1865 (Fs); Yuncker 17028 (Mi, S). HISPANIOIA: Dominican Kepublic: Abbott $498(W-1078620), 646$ (W--1078619), 648 (W1078621), $\overline{1026}(W-1078783), 1200$ (W-1078865); B. Augusto 1045

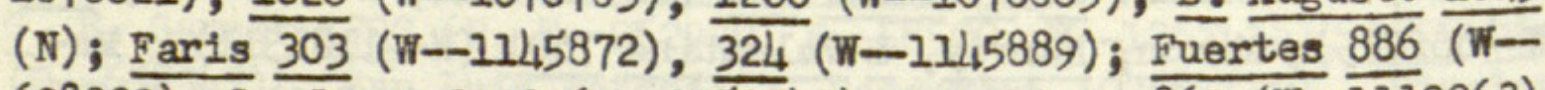
698029); C. Junge 2992 (W-2253742); Raunkiaer $\overline{869(W-1110063) ; ~}$ Valeur 443 (W-1273793); Wright, Parry, \& Brummel 354 (W-43512, W-43513). Hatti: Ekman H.7958 (W-1412858); E. C. Leonard 2943 $(W-1075189), 3101$ (W-1075358), 3302 (W-1075595, W-1075596), $5124_{4}(\mathrm{~W}-1077716), 5229(\mathrm{~W}-1077836)$, $7506 \mathrm{a}$ (W-1149369); Leonard \& Leonard 14389 (W-11452822), $15413(W-1453679)$. PUERTO RICO: Goll 68 (W-408661), $150($ W- 408737$), 675$ (W-409218); A. A. Hel-

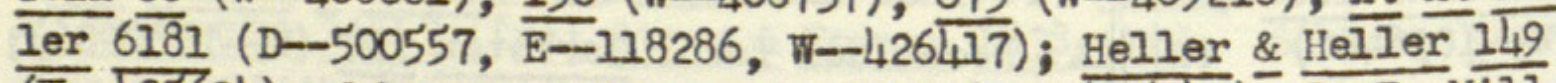
(W-- 425694$)$; Johnston \& Stevenson 1297 (W-1 1475943$) ;$ C. F. Millspaugh 337 (F-60337); Sintenis $15 \overline{7}(\mathrm{~W}--1323151), 1857$ (W$1323158)$; Undermood \& Griggs $201 \mathrm{a}$ (w-405934), 529 (T-L 405472$)$; Velez 2918 (N). VIEQUES: Shafer 2425 (W--759977). VIRGIN ISLANDS: St. Croix: A. E. Ricksecker 167 (Ca--473250, E-1118792, W--278058); L. A. Ricksecker 131 (E-118791, W-425294); Thompson $842(\mathrm{D}-61909 \overline{8}), 8 \overline{66}(\mathrm{D}-619082)$. St. John: Britton \& Shaferr 507 (T-756477). St. Thomas: Eggers $26(\mathbb{W}-11110232), \underline{365}$ (W1323152), s.n. [Novbr. 1882] (W-1323153), s.n. [Dec. 1886] (F1l1757); Ehrenberg 107 (E-114062); Krebs s.n. $(\mathrm{F}-131515)$. LEEWARD ISLANDS: Antigua: Box 1021 (N). Guadeloupe: Duchassaing s. n. $(\mathrm{B}-188790)$; Questel $456 \overline{6}(\mathrm{~W}-2453646)$. Montserrat: Shafer $\overline{138}$ (W-695158). WINDWARD ISLANDS: Barbados: Bovell \& Freeman s.

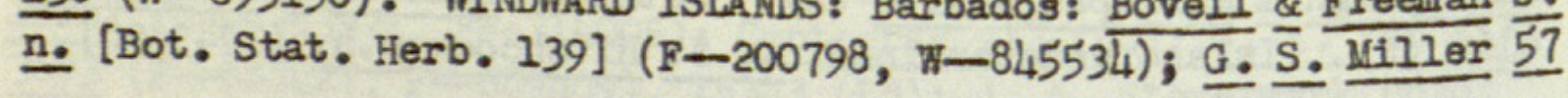




\section{$2 \mathrm{BHL}$ Biodiversity Heritage Library}

Moldenke, Harold N. 1967. "Additional notes on the genus Priva. IV." Phytologia 14, 336-357. https://doi.org/10.5962/bhl.part.18531.

View This Item Online: https://www.biodiversitylibrary.org/item/51598

DOI: https://doi.org/10.5962/bhl.part.18531

Permalink: https://www.biodiversitylibrary.org/partpdf/18531

\section{Holding Institution}

Missouri Botanical Garden, Peter H. Raven Library

\section{Sponsored by}

Missouri Botanical Garden

\section{Copyright \& Reuse}

Copyright Status: In copyright. Digitized with the permission of the rights holder.

Rights Holder: Phytologia

License: http://creativecommons.org/licenses/by-nc-sa/3.0/

Rights: https://biodiversitylibrary.org/permissions

This document was created from content at the Biodiversity Heritage Library, the world's largest open access digital library for biodiversity literature and archives. Visit BHL at https://www.biodiversitylibrary.org. 